\title{
Professor Jeffrey Jowell QC
}

Jeffrey Jowell, Professor of Public Law, Vice Provost and Dean of the Law Faculty Elect at University College, London, gives his views on the need for law schools to adopt radical changes to their traditional way of working.

Law schools should be considering how they can adapt and improve their teaching so that students will be properly equipped to cope with the problems confronting them in future. In the view of Professor Jeffrey Jowell QC there are four key issues to address - globalisation, information technology, lifelong learning, and the need for interdisciplinary study.

The first two issues are linked, as Professor Jowell explains:

'About half of the work done by some of the large firms of English solicitors is carried out abroad, and we must try to equip students to play their part. We must look at the facilities available which can help to achieve that, such as the use of information technology. It is also important to establish links with institutions all over the world and to make students comfortable with transitional concepts and practice.'

UCL and the other London law schools have the advantage of being close to a vast reservoir of knowledge in the form of people located in the capital who have experience in legal practice and research. Professor Jowell is keen to draw such individuals into a closer association with UCL.

'We have a special opportunity to involve practitioners in much more teaching and research and they can help give us direction. This brings us on to the need for lifelong learning, We are not producing the finished article any more, but people

equipped to learn for the rest of their lives who will keep accumulating skills. We have to produce the continuing learner and provide the continuing learning. The model for what we want does not exist any more in the old university law schools, if it ever did. Some of the great American law schools have followed this approach, which I also believe has perhaps best been developed in this country by some of the colleges of professional education (loath as some of the universities are to admit it)'.

Professor Jowell wants to see law schools providing strong and coherent undergraduate law courses coupled with a postgraduate programme where the deeper research skills are nurtured.

'It is important that we look at different ways of working. The London LLM is an embarrassment of riches, but I feel that there ought to be more interdisciplinary MAs covering law with subjects such as economics, politics, history, IT, philosophy, public policy including ethics. The core should remain the $L L B$ plus the LLM and PhD, but we do need to look beyond that structure. So many of our future problems will need for their resolution the skills of more than one discipline and methodology'.

The main threat to the future of legal research in Professor Jowell's view is the low pay of academics:

'My own view is that we would be better off halving the numbers of academic staff and doubling their pay overnight. I am very concerned that certain disciplines are in serious danger of withering on the vine. You only have to look back 10 years to

\section{CURRICULUM VITAE}

Professor Jowell has been Professor of Public Law at UCL since 1975 and Vice Provost since 1992. He was dean of UCL's Law Faculty throughout the 80's - a post which he will add to his present positions again from September 1998. He attended Cape Town University and Hertford College Oxford, becoming president of the Oxford Union, before gaining an LLM and SJD at Harvard. He was a Fellow of the Joint Centre for Urban Studies, Harvard and MIT, from 1967-78, and an Associate Professor at Osgoode Hall Law School, Toronto, from 1968-71. From 1972-74 he was Leverhulme Fellow in Urban Legal Studies and Lecturer in Law (1974-75) at the London School of Economics. Professor Jowell has produced several publications in areas including public decision-making, official discretion, planning law and judicial review. He is the author, with Lord Woolf, of the classic text by de Smith, now known as de Smith Woolf \&Jowell, Judicial Review of Administrative Action. He has served on the boards of a number of journals and charitable trusts and received an Honorary Queen's Council in 1993 and has three honorary degrees. He conducts an active practice at the Bar. remember that a proportion of our best and brightest law graduates were delighted and proud to become law teachers, and would feel fulfilled doing it. Now the pay differential is so great that it becomes almost foolish to give up the financial rewards of practice'

As someone who was born and brought up in South Africa, Professor Jowell understands the importance of a legal education which examines the impact of developments throughout the world. In 1990 - the year Nelson Mandela was released - Professor Jowell was invited to become a Visiting Professor at Cape Town, the university he first attended.

'I taught administrative law and human rights, and it was probably the most exciting teaching period of my life. The students were passionately interested, and there were many debates. I was asked to address the question 'Is a Bill of Rights a Bill for Whites?', by students who were concerned that a bill of rights would merely entrench the privileges of the white community, The discussions lasted long into the night'.

As a public lawyer, when I think about the term "globalisation" I see the common principles of democracy that are being accepted over so much more of the world than before. A common language is being developed and above all people are realising that certain rules and principles are inherent in any democracy worthy of the name. That surely makes public law an exciting subject and the framework within which much other law is placed.

Professor Jowell has contributed his own expertise to the drafting of the new South African constitution and co-ordinated gatherings of committees of experts who created the country's bill of rights. The knowledge gained from this exercise is of relevance when considering the implications for the UK of incorporating the European Convention on Human Rights into domestic law.

Recently Professor Jowell found himself sharing a platform with the South African constitutional judge and former activist Albie Sachs at a lecture entitled The lessons from South Africa for British human rights'. There could be no greater testament to the speed of change than the title of this talk - or the potency of the human rights message.

\section{Interviewed by Julian Harris} Senior Information Officer

Institute of Advanced Legal Studies 